\title{
Building Resilience through Farmers' Experiments in Organic Agriculture: Examples from Eastern Austria
}

\author{
Susanne Kummer, ${ }^{1, *}$, Rebecka Milestad $^{2,{ }^{*}}$, Friedrich Leitgeb ${ }^{1} \&$ Christian R. Vogl ${ }^{1}$ \\ ${ }^{1}$ Division of Organic Farming, Department of Sustainable Agricultural Systems, University of Natural \\ Resources and Life Sciences, Vienna, Austria \\ ${ }^{2}$ Department of Urban and Rural Development, Swedish University of Agricultural Sciences, Uppsala, Sweden \\ \& Division of Environmental Strategies Research, Royal Institute of Technology, Stockholm, Sweden \\ Correspondence: Susanne Kummer, Department of Sustainable Agricultural Systems, University of Natural \\ Resources and Life Sciences, Vienna, Austria. E-mail: susanne.kummer@boku.ac.at
}

* Equally contributing authors

Received: April 13, 2012 Accepted: May 28, 2012 Online Published: July 31, 2012

doi:10.5539/sar.v1n2p308 URL: http://dx.doi.org/10.5539/sar.v1n2p308

\begin{abstract}
Farmers have always lived in changing environments where uncertainty and disturbances are inevitable. Therefore, farmers need the ability to adapt to change in order to be able to maintain their farms. Experimentation is one way for farmers to learn and adapt, and may be a tool to build farm resilience. Farmers' experiments as defined in this paper are activities where something totally or partially new is introduced at the farm and the feasibility of this introduction is evaluated. The theoretical framework applied to study farmers' experiments is the concept of resilience. Resilience is the capacity of social-ecological systems to cope with change, and is a framework used to assess complex systems of interactions between humans and ecosystems.

This paper explores to which extent farmers' experimentation can help build farm resilience. In addition to arguments found in the literature, five organic farms in Eastern Austria are used to illustrate this potential. The farmers were interviewed in 2007 and 2008. The respective farmers all worked fulltime on their farms, were between 34 and 55 years old, and owned farms between 15 and 76 ha. These farmers experimented in ways that enhance resilience - at the farm and in the region. The outcome of experiments can be management changes, new insights, or technology that can be passed on and potentially be built into education and advisory institutions. To encourage farmers' experiments, it is important to develop conditions that support farmers in their experimenting role.
\end{abstract}

Keywords: farmers' experiments, organic farming, social-ecological resilience, local knowledge, Austria

\section{Introduction}

Changes that impact agriculture, such as rising energy prices, market fluctuations, climate change, or current trends such as the increasing pace of which farms are closed down in Europe, raise the question how to sustain ecosystem services from agriculture. Farmers face dynamics and disturbances at the farm, induced by local, regional, national or global trends or shocks. Thus, farmers need the ability to cope with, adapt to and shape change (Folke, Colding, \& Berkes, 2003). In other words, farmers need to build resilience of their farm (Milestad \& Darnhofer, 2003). Resilience theory has emerged as a powerful concept in the sustainability discourse. A resilient system has the capacity to absorb disturbance and reorganise while undergoing change so as to still retain essentially the same function, structure, identity and feedbacks (e.g. Carpenter, Walker, Anderies, \& Abel, 2001; Walker, Holling, Carpenter, \& Kinzig, 2004). Thus, resilience is the capacity to cope with change, since there is no such thing as an ever-stable system. Because of the dynamic and complex nature of farming systems, and because we are dealing here with an interdependence between humans and ecosystems, i.e. agro-ecosystems, resilience theory can be a useful framework when analysing farms regarding their ability to cope with change (Milestad \& Darnhofer, 2003; Darnhofer, 2010).

An important component of resilience is learning, and one way to learn is trying new things or experimenting (Armitage, Marschkeb, \& Plummerc, 2008). Indeed, experimentation is one of the fundamental strategies involved in farmers' learning (Rhoades \& Bebbington, 1991). The development of locally adapted farming systems 
worldwide can be ascribed to the continuous experimentation activities of farmers (Hoffmann, Probst, \& Christinck, 2007). Farmers' experiments enable farmers to adapt to ever changing circumstances (Bentley, 2006), build the base for countless agricultural innovations (Leitgeb, Funes-Monzote, Kummer, \& Vogl, 2011), and are a means to generate local knowledge (Sumberg \& Okali, 1997). Knowledge-generating capacity is needed if sustainability and development goals are to be reached (International Assessment of Agricultural Knowledge, Science and Technology for Development [IAASTD], 2009).

Developing new knowledge and learning processes strengthen farmers' capacity to deal with change (Milestad, Westberg, Geber, \& Björklund, 2010). However, farmers' own experiments have not been analysed in a resilience framework in any previous study. In this paper we explore the particular case of farmers' experiments and how these can contribute to social-ecological resilience on farms. A resilience framework could provide one way to explore and better understand how farmers' experiments contribute to sustainable development. We base our research on the literature on farmers' experiments and resilience, and additionally use case studies of experimenting farmers, experimenting on different levels and aspects of farm management. We analyse farmers' experiments taking four principles that build social-ecological resilience from Folke et al. (2003) as a point of departure: learning to live with change and uncertainty, nurturing diversity for reorganisation and renewal, combining different types of knowledge for learning, and creating opportunity for self-organisation.

There are two reasons why we focus on organic farmers when exploring farmers' experiments. First, while conventional farmers can use external inputs such as synthetic pesticides and synthetic fertilisers to buffer adverse dynamics in their agro-ecosystem, organic farmers need to develop knowledge about the agro-ecosystem to a larger extent to be able to manage their farms successfully without these inputs. Second, organic farming was developed by farmer grassroots organisations, where farmers themselves were responsible for advances and innovations. The lack of advice and formal research in the pioneer phase of organic farming brings forth the assumption that organic farmers have developed a culture of experimentation.

\subsection{A Resilience Framework for Farmers' Experiments}

Resilience has proven difficult to measure and operationalise (Bennet, Cumming, \& Peterson, 2005; Cumming et al., 2005). One attempt was made by Folke et al. (2003). Based on a number of case studies they suggest four principles that build resilience in social-ecological systems. The first, learning to live with change and uncertainty, focuses on the need to learn from crises and to acknowledge the existence of uncertainty and surprise in development. Management actions on the farm may include spreading risks e.g. by diversification.

The second, nurturing diversity for reorganisation and renewal, emphasises the need to use ecological and social diversity when coping with change. Ecological diversity consists of the diversity of species within and between functional groups (Nyström \& Folke, 2001). Farmers that use and enhance biodiversity in their experiments nurture ecological diversity. In the social realm, diversity is enhanced when individuals, institutions, organisations, and other actors have different and overlapping roles.

The third, combining different types of knowledge for learning, acknowledges that both scientific and popular knowledge are important to develop local ecological knowledge needed to build resilience. Thus, the knowledge of different actors and groups are relevant. Further, Folke et al. (2003) suggest that knowledge about ecosystem processes and functions is the most important kind of knowledge when building resilience.

Finally, Folke et al. (2003) suggest creating opportunity for self-organisation toward social-ecological sustainability as the fourth principle. This relates to the ability of farmers to maintain capacity for self-organisation rather than relying on external intervention (Berkes, 2007). It also involves taking cross-scale issues into account, such as the impacts of external drivers on the farm (e.g. market fluctuations or policy changes).

\subsection{Farmers' Learning through Experimentation}

Farming systems have been described from a variety of angles and with differing purposes. One research tradition concerns the knowledge and technology development of farmers, their interaction with formal research and farmers' strategies to cope with and adapt to changes (Scoones \& Thompson, 1994; Sumberg \& Okali, 1997; Ellis, 2000; Hoffmann et al., 2007). In this research field, farmers' experiments are considered a management method to deal with dynamics and changes that occur. Experimentation is one of the fundamental strategies involved in farmers' learning (Rhoades \& Bebbington, 1991).

Historically, farmers' experimentation and innovation have been the means through which technological advances have been made (Chambers, Pacey \& Thrupp, 1989; Critchley, 2000). Testing new methods and technologies is an integral and common element in the daily life of farmers (Haverkort, 1991; Scheuermeier, 1997; Sumberg \& Okali, 1997; Bentley, 2006; Richards \& Suazo, 2006). Farmers adopt, adapt and formulate new ideas, try them out in 
different settings, evaluate the results, and make decisions on their value for improving the farm. All of these knowledge-generating activities, no matter what methods they employ, can be referred to as farmers' experiments (Van Veldhuizen, Waters-Bayer, Ramirez, Johnson, \& Thompson, 1997; Leitgeb et al., 2011).

In the context of this article, we define farmers' experiments as the activity of introducing something totally or partially new at the farm and to evaluate the success or failure of this introduction (Quiroz, 1999), or as the comparison of something known with something unknown (Stolzenbach, 1999). As Sumberg and Okali (1997), we consider two conditions necessary for an activity to be labelled an experiment: the creation or initial observation of conditions, and the observation or monitoring of subsequent results. We do not refer to scientist-led on-farm research, or to research-like procedures induced by advisory agencies (cf. Wilbois et al., 2004), but to farmers' endogenous experimentation activities. Farmers' experiments differ from scientific experiments in the sense that they are conducted in everyday circumstances, and are an integral part of farming (Röling \& Brouwers, 1999).

Farmers experiment by themselves, out of necessity, interest or curiosity (Rhoades \& Bebbington, 1991; Sumberg \& Okali, 1997; Saad, 2002), but they may also take up information and techniques offered by research and advisory work. These off-farm resources can be integrated and adapted to the local conditions of the farm and the specific needs of the farmer or the farming family by experimentation.

Many authors agree that all farmers have experimental capacity (Johnson, 1972; Rhoades \& Bebbington, 1991; Quiroz, 1999; Stolzenbach, 1999; Critchley \& Mutunga, 2003; Bentley, 2006). However, this does not mean that all farmers are innovative and are able to cope with changing conditions (Quiroz, 1999). Some farmers may not be interested in experimenting. In addition, policies, regulations and subsidy systems may inhibit or support farmers' experiments. Experimenting farmers are not a homogenous group (Sumberg \& Okali, 1997), but some similarities can be found. For example, many have travelled to, and experienced other areas (Critchley \& Mutunga, 2003), are devoted to full time farming and are flexible enough to be able to experiment (Reij \& Waters-Bayer, 2001).

While no previous study has linked farmers' experiments with resilience, there are many links between these two concepts in literature. Farmers' experiments are related to resilience thinking since the process of testing knowledge is vital for building social-ecological resilience (Berkes \& Turner, 2006). Learning through experimentation and innovation is necessary to develop and test knowledge that potentially helps to cope with change and uncertainty (Walker, Gunderson, Kinzig, Folke, Carpenter, \& Schultz, 2006). An important question is to what extent local knowledge development (e.g. through experimentation) helps monitor, interpret, and respond to dynamic changes in the context in which farmers live (Berkes, Colding, \& Folke, 2000). Local knowledge is a living resource that is constantly reinvented. Farmer expertise is an indispensable element in sustainable agriculture, i.e. sustainable agriculture requires farmers to be experts in managing complex systems (Pretty, 1998; Röling \& Brouwers, 1999).

\section{Methods}

This paper draws on the literature available on farmers' experiments and resilience. Because of the lack of literature in the European context, and in order to add empirical examples, we also used partial results from a three-year research project, where topics, methods and outcomes of organic farmers' experiments were investigated (Kummer, 2011). Semi-structured interviews were carried out with a purposefully selected sample of organic farmers in Austria in the years 2007 and 2008. For this paper, five of these farms were selected to illustrate the connection between farmers' experiments and resilience. We selected these five farmers or farmer couples because they explicitly conducted experiments and considered trying and experimenting important activities within farm management. Furthermore, these farmers were well known as organic pioneers or innovators in their region due to their new or exceptional farming practices, and are recognized for their knowledge of these practices. The selected cases are therefore not representative for all organic farmers in Austria, but for a subgroup of active experimenters. They are presented in detail in Table 1.

An additional selection criterion was that the farms were all located in a similar environment; in this case in Eastern Austria. This area is characterized by flat to hilly lowlands and temperate, inland climate, as well as high external input agriculture. Agriculture in this region is characterised by crop production and intensive pig and poultry production. The percentage of organic farms in Eastern Austria is lower than in the Western, Alpine regions of Austria. This is represented by the fact that $25 \%$ of the Austrian permanent grassland (mainly located in the Alpine regions of Austria) is under organic management, while only $14 \%$ of the arable land in Austria is managed according to organic standards (Bundesministerium für Land- und Forstwirtschaft, Umwelt und Wasserwirtschaft [BMLFUW], 2011).

Organic farmers in Eastern Austria produce a wide range of products, mainly cereals, wine, and vegetables. Due to 
the relative proximity to the Vienna metropolitan area (1.7 million inhabitants) some organic farmers have found niches selling directly to consumers, while the majority sell through large middlemen and retailers serving the Viennese and national market.

Data was collected in individual semi-structured interviews (Miles \& Huberman, 1994; Bernard, 2006) on the selected farms. In the interviews, we did not use the term 'experimenting', as this term is frequently associated with a formal scientific procedure. In various empirical studies on the topic, the term 'trying' instead of 'experimenting' has been seen as being more appropriate (Sumberg \& Okali, 1997), while in other cases local terms were used to address the subject in the field (Stolzenbach, 1999). Based on these considerations from literature, we used the term 'trying', so to leave the definition of experimentation activities open to the emic perception of the farmers (Kummer, 2011).

The interviews were recorded and transcribed. Coding was done with the help of the software package Atlas.TiC. We used qualitative content analysis based on deductive and inductive coding (Miles \& Huberman, 1994; Bernard, 2006). Interview data was analysed along the four principles of social-ecological resilience defined by Folke et al. (2003). The farmer experiments and activities presented in the results section are allocated to these four principles. Frequently, these activities are not distinct experiments, but comprise different aspects of the same experiment the farmers conducted.

Table 1. Description of the selected cases

\begin{tabular}{|c|c|c|c|c|c|}
\hline Cases & F.1 & F.2 & F.3 & F.4 & F.5 \\
\hline Farmer & male, 45 years & male, 55 years & $\begin{array}{c}\text { couple, } 47 \text { / } 51 \\
\text { years }\end{array}$ & male, 34 years & male, 47 years \\
\hline Size of farm & 76 ha & 70 ha & $15 \mathrm{ha}$ & 50 ha & 61 ha \\
\hline Employment & fulltime farmer & fulltime farmer & fulltime farmers & fulltime farmer & fulltime farmer \\
\hline Organic since & 1994 & 1982 & 1989 & 2002 & 1989 \\
\hline Production & $\begin{array}{c}\text { grains, potatoes, } \\
\text { feed-grain, } \\
\text { legumes }\end{array}$ & $\begin{array}{l}\text { wine, fruit juice, } \\
\text { grains, direct } \\
\text { marketing (wine) }\end{array}$ & $\begin{array}{l}\text { grains, sheep } \\
\text { (cheese, meat), } \\
\text { wine, vegetables }\end{array}$ & $\begin{array}{c}\text { free range pigs, } \\
\text { processing of } \\
\text { meat, } \\
\text { pumpkinseed oil }\end{array}$ & $\begin{array}{c}\text { grains, vegetables, } \\
\text { herbs }\end{array}$ \\
\hline $\begin{array}{l}\text { Other farming } \\
\text { activities }\end{array}$ & $\begin{array}{l}\text { advisory services } \\
\text { for farmers } \\
\text { (no-plough } \\
\text { tillage) }\end{array}$ & $\begin{array}{l}\text { guided farm tours, } \\
\text { wine tasting, } \\
\text { cooperation with } \\
\text { research } \\
\text { institutions }\end{array}$ & $\begin{array}{l}\text { excursions and } \\
\text { courses for pupils, } \\
\text { students and } \\
\text { consumers at farm }\end{array}$ & $\begin{array}{l}\text { cofounders of an } \\
\text { alternative school } \\
\text { in the region }\end{array}$ & $\begin{array}{l}\text { cooperation with } \\
\text { research } \\
\text { institutions }\end{array}$ \\
\hline $\begin{array}{l}\text { Additional } \\
\text { information } \\
\text { about the } \\
\text { farmer/s }\end{array}$ & $\begin{array}{l}\text { pioneer and early } \\
\text { adopter of } \\
\text { no-plough } \\
\text { tillage, } \\
\text { no livestock }\end{array}$ & $\begin{array}{l}\text { organic pioneer, } \\
\text { regional } \\
\text { role-model for } \\
\text { organic farming, } \\
\text { no livestock }\end{array}$ & $\begin{array}{l}\text { organic pioneers, } \\
\text { diversified farm, } \\
\text { direct marketing }\end{array}$ & $\begin{array}{l}\text { novice organic } \\
\text { farmer, widely } \\
\text { known for free } \\
\text { range pigs }\end{array}$ & $\begin{array}{l}\text { organic pioneer, } \\
\text { comparably high } \\
\text { crop diversity, } \\
\text { no livestock }\end{array}$ \\
\hline $\begin{array}{l}\text { Experiment/s } \\
\text { mainly with }\end{array}$ & $\begin{array}{l}\text { no-plough } \\
\text { tillage, direct } \\
\text { sowing, } \\
\text { intercropping }\end{array}$ & $\begin{array}{l}\text { organic remedies } \\
\text { and methods } \\
\text { against mildew in } \\
\text { vines }\end{array}$ & $\begin{array}{l}\text { vegetable } \\
\text { varieties, } \\
\text { vegetable growing } \\
\text { without irrigation, } \\
\text { organic viticulture }\end{array}$ & $\begin{array}{l}\text { feedstuff for pigs, } \\
\text { handling of } \\
\text { rearing sows }\end{array}$ & $\begin{array}{c}\text { cultivation of } \\
\text { specialized crops, } \\
\text { intercropping, seed } \\
\text { production }\end{array}$ \\
\hline
\end{tabular}

\section{Results and Discussion}

This article builds its argument primarily based on available literature on farmers' experiments and social-ecological resilience. Due to the lack of previous research on farmers' experiments in a European context, however, we have added five cases of experimenting farmers in order to illustrate our argument and add depth to the discussion. Thus, this section takes the defining characteristics of social-ecological resilience proposed by Folke et al (2003) as a point of departure together with the literature on farmers' experiments in order to find arguments for how farmers' experiments can build resilience for (organic) farms. Adding to this, we include the five cases to explore what experiments these farmers carry out that can be argued to build resilience.

\subsection{Learning to Live with Change and Uncertainty}

To build farm resilience, there has to be knowledge, practices and social mechanisms taking into account that dynamics like disturbance, change and crisis are part of development (Folke et al., 2003). These dynamics can 
emerge from events on the farm, or from outside the farm. Both internal and external influences can motivate farmers to try new things, and change management practices as a result (Bentley, 2006). For example, changes in farmers' economic realities or a need to save on labour or capital, or both, can induce farmers to experiment (Critchley, 2000; Bentley, 2006). Other motives and triggers for experimentation range from response to disaster, social responsibility, peer pressure, problem solving and curiosity (Rhoades \& Bebbington, 1991; Millar, 1994; Van Veldhuizen et al., 1997; Gupta, 2000; Buchmann, 2009). In the cases described (Table 2), the reasons for experimentation included crop production failures (F.1), crop diseases (F.2, F.3) and high losses of piglets (F.4).

Experiments can be tools to help farmers to deal with emerging crises (Quiroz, 1999). Results and insights from earlier experiments provide useful knowledge and practical solutions that farmers can use in case of an emerging crisis. Further, experiments may help farmers to shape their farming system so that a crisis does not have harmful impacts. It is also possible that a crisis can be used as an opportunity for development. Turning crisis into opportunity is characteristic for resilient systems (Folke et al., 2003). For example, farmer F.1 (Table 2) experimented with no-plough tillage, direct sowing and intercropping as a response to decreased soil fertility and crop failures. The farmer used the crisis to develop a fully new cropping system, which was better adapted to the climatic conditions and soil structure of the farm.

Spreading risks is important when living with uncertainty. Examples of risk-spreading and insurance building strategies can be found in the context of the conversion to organic farming. Many farmers experiment with organic production methods before they decide to convert. Experiments and the knowledge they generate help farmers to decide whether organic farming is suitable for themselves and their farms. Thereby farmers reduce the risk of making the wrong decision (Padel, 2001). For example, farmer F.5 (Table 2) experimented with organic crop and vegetable production before officially converting his farming system to organic production.

Management measures that are first tried on a small scale are also examples of risk-spreading strategies (Sturdy, Jewitt \& Lorentz, 2008). For example, a farmer experiments with a new crop or management technique in a small field or in the garden before the crop or management technique is used on larger fields (Saad, 2002). Starting on the small scale allows farmers to collect experiences of the new crop or management technique in a safe manner. For example, farmer F.2 (Table 2) tried remedies for powdery mildew (Oidium tuckeri) on grapes in parts of the vineyards and only scaled up after careful evaluation. Farmer F.4 started to experiment with free-range pig keeping with three sows and one boar before successively expanding to more than 200 pigs.

Table 2. Learning to live with change and uncertainty through farmers' experiments (examples)

\begin{tabular}{|c|c|c|c|}
\hline Farmer & Change/Uncertainty & Description of experiment & $\begin{array}{l}\text { Outcomes of experiment } \\
\text { (relevance for resilience) }\end{array}$ \\
\hline F.1 & Decreasing soil fertility & $\begin{array}{c}\text { Experiments with no-plough tillage and } \\
\text { direct sowing }\end{array}$ & $\begin{array}{l}\text { Reduced soil erosion, enhanced } \\
\text { soil fertility, improved structure } \\
\text { and biological activity of the soil, } \\
\text { enhanced drought tolerance }\end{array}$ \\
\hline F.1 & Diminishing yields & $\begin{array}{l}\text { Experiments about intercropping of two to } \\
\text { four crops }\end{array}$ & Secure harvest even in dry years \\
\hline F.2 & $\begin{array}{l}\text { Fungal infections with } \\
\text { powdery mildew (Oidium } \\
\text { tuckeri) in vineyards }\end{array}$ & $\begin{array}{l}\text { Experiments about early detection of risk } \\
\text { for fungal infections, using a vineyard in } \\
\text { disadvantaged location with wet } \\
\text { microclimate as indicator }\end{array}$ & $\begin{array}{l}\text { Vineyard served as an early } \\
\text { warning system for fungal } \\
\text { infections and as indicator for } \\
\text { effectiveness of remedies against } \\
\text { fungal infections }\end{array}$ \\
\hline F.2 & $\begin{array}{l}\text { Effectiveness of different } \\
\text { organic remedies against } \\
\text { mildew infections }\end{array}$ & $\begin{array}{l}\text { Small-scale experimentation: Application } \\
\text { of remedies only in one third of two to } \\
\text { three vineyards; accurate evaluation of } \\
\text { effectiveness (direct comparison) }\end{array}$ & $\begin{array}{l}\text { Clearness about effectiveness of } \\
\text { methods/remedies; scaling up of } \\
\text { most effective methods }\end{array}$ \\
\hline F.2 & $\begin{array}{l}\text { Effectiveness of specific } \\
\text { remedy }\end{array}$ & $\begin{array}{l}\text { Experimentation with applications of } \\
\text { sodium bicarbonate }\end{array}$ & $\begin{array}{c}\text { Sodium bicarbonate was approved } \\
\text { as efficient organic remedy that } \\
\text { does not generate resistance of the } \\
\text { pathogen }\end{array}$ \\
\hline F.3 & $\begin{array}{l}\text { Heavy powdery mildew } \\
\text { infections }\end{array}$ & $\begin{array}{l}\text { Experiments with grafting sensitive vines } \\
\text { with mildew tolerant varieties }\end{array}$ & $\begin{array}{l}\text { More mildew tolerant vine } \\
\text { varieties, less mildew infections }\end{array}$ \\
\hline F.3 & $\begin{array}{l}\text { Suitability of vegetable } \\
\text { varieties for local } \\
\text { conditions }\end{array}$ & $\begin{array}{l}\text { Experimenting with new vegetable species } \\
\text { and varieties in the home garden }\end{array}$ & $\begin{array}{l}\text { Appropriate varieties for regional } \\
\text { conditions; expansion of best } \\
\text { suited crops to vegetable } \\
\text { allotments }\end{array}$ \\
\hline
\end{tabular}




\begin{tabular}{|c|c|c|c|}
\hline F.4 & $\begin{array}{l}\text { Test new animal } \\
\text { husbandry system with } \\
\text { little risk }\end{array}$ & $\begin{array}{l}\text { Small-scale experiments about free-range } \\
\text { pig keeping, starting with three sows and } \\
\text { one boar }\end{array}$ & $\begin{array}{l}\text { Possibility to observe and learn } \\
\text { with little risk; successful } \\
\text { implementation and expansion of } \\
\text { free-range pig production system }\end{array}$ \\
\hline F.4 & $\begin{array}{l}\text { High losses of piglets in } \\
\text { free-range pig herds }\end{array}$ & $\begin{array}{l}\text { Experiments with handling of rearing } \\
\text { sows: Dividing breeding herd into } \\
\text { subgroups, separating sows from the herd } \\
\text { before parturition; direct observation and } \\
\text { historical comparison to prove efficiency }\end{array}$ & $\begin{array}{l}\text { Reduced stress and rivalry in } \\
\text { breeding herd, reduced piglet } \\
\text { losses }\end{array}$ \\
\hline F.5 & $\begin{array}{l}\text { Test organic production } \\
\text { methods before conversion }\end{array}$ & $\begin{array}{l}\text { Experiments with organic cropping } \\
\text { techniques in an area of intensive } \\
\text { conventional agriculture }\end{array}$ & $\begin{array}{c}\text { Relatively low risk of failure when } \\
\text { officially converting to organic } \\
\text { farming }\end{array}$ \\
\hline F.5 & Test new crops or varieties & $\begin{array}{l}\text { Small-scale experiments with new crops; } \\
\text { observation and evaluation of market } \\
\text { demand for the crops }\end{array}$ & $\begin{array}{l}\text { Informed decision about crops that } \\
\text { fit into production system }\end{array}$ \\
\hline
\end{tabular}

\subsection{Nurturing Diversity for Reorganisation and Renewal}

Diversity is an important aspect of farmers' capacity to build social-ecological resilience (Cumming et al., 2005; Berkes, 2007). A high degree of specialisation reduces the ability of a system to adapt (Hendrickson, Sassenrath, Archer, Hanson, \& Halloran, 2008). Diversity gives complex systems the ability to cope with change at the same time as it offers the potential for reorganising after change (Carpenter et al., 2001). Compared to the simplified ecosystems created by agro-industrial monocultures, many traditional or alternative farming systems use and maintain a diversity of resources that provide broader livelihood portfolios and/or increased on-farm biodiversity (Berkes, 2007; Björklund, Westberg, Geber, Milestad, \& Ahnström, 2009).

A common type of experiment is the testing of new crops and varieties. Farmers can use biodiversity to find suitable crops and varieties of crops for their farms (Bentley, 2006). All farmers presented in this study experimented with biodiversity in some way (Table 3). For example, farmers F.1 and F.5 experimented with different mixed cultures to find the best proportion between the types of crops for intercropping, and to find the right species and varieties. Farmer F.2 experimented with wild plants that he thought might stimulate growth of vines. Farmers F.3, F.4 and F.5 experimented with crops to find varieties and species suitable for their farming conditions. Farmer F.1 mimicked natural grasslands when trying to find the appropriate proportion between grasses and legumes for his fields. Farmer F.4 used native and rare pig breeds for his free-range pig keeping.

Diversity is important in the social realm as well. Increasing the diversity of actors has the potential of bringing new thinking and expanding the role of information, education and dialogue (Berkes, 2007). Social memory consists of a diversity of individuals, institutions, organizations and other players with different but overlapping roles (Folke et al., 2003). Experimenting farmers can have the role of e.g. innovators, entrepreneurs, networkers and/or knowledge carriers (Folke et al., 2003). Farmers that experiment and develop new management practices and new knowledge enhance social memory in the organic farming movement as well as in the region where the farm is situated through stimulating discussion, change and learning (Kroma, 2006). All five selected farmers were well known for their innovative practices and the knowledge and experience they had built through experimenting (Table 3). Farmers F.1, F.2, F.3 and F.5 were pioneers of organic farming (see Tables 1 and 3). All farmers actively exchanged and passed on their knowledge, e.g. by communicating it to colleagues and advisors, by holding farmer meetings, or by inviting students and interested consumers onto their farms. Thus, the outcomes from experiments were passed on and exchanged with people outside the farms. The social activities (Table 3) are not experiments per se, but can be considered the next step after the experiment. However, since these activities are so closely connected to the actual on-farm experiment, the social activities are listed in Table 3 as experiments. 
Table 3. Nurturing diversity through farmers' experiments (examples)

\begin{tabular}{|c|c|c|c|}
\hline Farmer & $\begin{array}{l}\text { Nurturing diversity } \\
\text { by }\end{array}$ & Description of experiment/activity & $\begin{array}{l}\text { Outcomes of experiment } \\
\text { (relevance for resilience) }\end{array}$ \\
\hline F.1 & $\begin{array}{l}\text { Diversifying crops in } \\
\text { the field } \\
\text { (intercropping) }\end{array}$ & $\begin{array}{l}\text { Experiments on intercropping of different crops, } \\
\text { using natural plant communities as a model (e.g. } \\
\text { proportion of grass/cereals and legumes) }\end{array}$ & $\begin{array}{l}\text { Diversified, optimized plant } \\
\text { combinations }\end{array}$ \\
\hline F.1 & $\begin{array}{l}\text { Enhancing social } \\
\text { memory }\end{array}$ & $\begin{array}{c}\text { Acting as practical advisor and establishing } \\
\text { regional farmer group, stimulating farmers to } \\
\text { experiment with innovative methods for arable } \\
\text { systems }\end{array}$ & $\begin{array}{l}\text { Spreading experiences with } \\
\text { alternative cropping systems in } \\
\text { the farming community, } \\
\text { motivating other farmers to } \\
\text { experiment }\end{array}$ \\
\hline F.2 & $\begin{array}{l}\text { Practical research } \\
\text { about wild plants in } \\
\text { vineyard }\end{array}$ & $\begin{array}{c}\text { Observation that different plants that grow in the } \\
\text { vineyard either support or inhibit growth of vines; } \\
\text { collection of seeds and propagation of wild plant } \\
\text { species to test positive and negative effects on } \\
\text { vines }\end{array}$ & $\begin{array}{l}\text { Knowledge on supporting and } \\
\text { inhibiting wild plant species in } \\
\text { vineyards; farmer was awarded a } \\
\text { national environmental prize for } \\
\text { this practical research project }\end{array}$ \\
\hline F.2 & $\begin{array}{l}\text { Diversifying regional } \\
\text { farming community } \\
\text { towards organic } \\
\text { farming }\end{array}$ & $\begin{array}{l}1 \text { Acting as pioneer for organic wine growing in the } \\
\text { region; being an example and spreading } \\
\text { knowledge built up through own experiments }\end{array}$ & $\begin{array}{l}\text { Motivating neighbouring farmers } \\
\text { to convert to organic farming; } \\
\text { advising other farmers }\end{array}$ \\
\hline F.3 & $\begin{array}{l}\text { Enhancing on-farm } \\
\text { vegetable diversity }\end{array}$ & $\begin{array}{l}\text { Conducting experiments with different vegetable } \\
\text { species and varieties (also rare/heirloom) to find } \\
\text { appropriate crops }\end{array}$ & $\begin{array}{l}\text { High diversity of vegetable } \\
\text { varieties that are adapted to local } \\
\text { farming system without need of } \\
\text { irrigation in dry area }\end{array}$ \\
\hline F.3 & $\begin{array}{l}\text { Sharing knowledge to } \\
\text { enhance social } \\
\text { memory }\end{array}$ & $\begin{array}{l}\text { Networking with farmers and consumers; } \\
\text { advising local organic farmer to establish } \\
\text { 'self-harvest' allotments (see Vogl, Axmann \& } \\
\text { Vogl-Lukasser, 2004) }\end{array}$ & $\begin{array}{l}\text { Intensive knowledge } \\
\text { transmission with local farmers } \\
\text { and consumers }\end{array}$ \\
\hline F.4 & $\begin{array}{l}\text { Enhancing on-farm } \\
\text { biological diversity }\end{array}$ & $\begin{array}{c}\text { Using rare, robust pig breeds as base for } \\
\text { experiments on free-range pig keeping; } \\
\text { Experimenting with alternative crops, e.g. } \\
\text { sunchoke (Helianthus tuberosus) as fodder base } \\
\text { for the pigs }\end{array}$ & $\begin{array}{l}\text { Robust, diversified free-range } \\
\text { pig production system (breeds, } \\
\text { fodder components) }\end{array}$ \\
\hline F.4 & $\begin{array}{l}\text { Enhancing social } \\
\text { memory of local } \\
\text { farmers and school } \\
\text { children }\end{array}$ & $\begin{array}{l}\text { Establishing exceptional free-range pig } \\
\text { husbandry, attracting interested farmers, scientists } \\
\text { and consumers; establishing alternative school } \\
\text { that is tightly linked with organic farm } \\
\text { (excursions to the farm, implementation of } \\
\text { practical garden experiments) }\end{array}$ & $\begin{array}{l}\text { Knowledge transmission with } \\
\text { local farmers, integration of } \\
\text { farming activities and practical } \\
\text { experiments into education } \\
\text { system }\end{array}$ \\
\hline F.5 & $\begin{array}{c}\text { Enhancing } \\
\text { biodiversity of arable } \\
\text { system }\end{array}$ & $\begin{array}{l}\text { Comparative experiments with different crops and } \\
\text { intercropping with different crop mixtures }\end{array}$ & $\begin{array}{l}\text { Detection of appropriate crops } \\
\text { for local conditions, diversified } \\
\text { cropping system }\end{array}$ \\
\hline F.5 & $\begin{array}{l}\text { Enhancing social } \\
\text { memory of farming } \\
\text { community }\end{array}$ & $\begin{array}{l}\text { Acting as pioneer and advisor in organic crop } \\
\text { production in a region with few organic farmers }\end{array}$ & $\begin{array}{c}\text { Diffusion of extensive } \\
\text { knowledge about organic crop } \\
\text { production, support for local } \\
\text { farmers }\end{array}$ \\
\hline
\end{tabular}

\subsection{Combining Different Types of Knowledge for Learning}

When experimenting, farmers use different types of knowledge coming from a multitude of sources such as other farmers, media, science, or extension service (Bentley, 2006). In this way, farmers can combine different knowledge systems and thus use knowledge developed on their own farm in combination with knowledge developed by research institutions or knowledge from other sources (Stolzenbach, 1999 ; Sturdy et al., 2008). A bi-directional flow of information from producers to researchers allows farmers to use the best possible information suited for their farms (Hendrickson et al., 2008). This is important since maintaining sustainable resource use relies on the combination of different knowledge systems (Alcorn, Bamba, Masiun, Natalia \& Royo, 2003). Formal and informal research is complementary and may create synergies (Hoffmann et al., 2007). In the Austrian cases, farmers F.2, F.4 and F.5 cooperated with research institutions to conduct experiments and exchange experiences (Table 4). Farmer F.2 actively used scientific literature to inspire new experiments and to compare with his own results. All five farmers used knowledge from outside the farm to inspire new experiments. 
In order to build social-ecological resilience, the knowledge developed in experiments requires social networks and institutional frameworks to be sustained effectively (Folke et al., 2003). Farmers that communicate, discuss and exchange results from experiments expand this knowledge into networks and institutions (Wu \& Pretty, 2004). In the cases (Table 4) all farmers had networks of colleagues, consumers and/or advisors and/or scientists for the exchange of knowledge developed during experiments, so the knowledge of all five farmers was passed on in the farmers' networks and into research and education institutions.

Table 4. Combining different types of knowledge for learning through farmers' experiments (examples)

\begin{tabular}{|c|c|c|c|}
\hline Farmer & $\begin{array}{l}\text { Knowledge } \\
\text { sources }\end{array}$ & Description_of experiment/activity & $\begin{array}{l}\text { Outcomes of experiment } \\
\text { (relevance for resilience) }\end{array}$ \\
\hline F.1 & $\begin{array}{l}\text { Own experience, } \\
\text { information of } \\
\text { other farmers, } \\
\text { scientists, experts }\end{array}$ & $\begin{array}{l}\text { Experimenting on no-plough tillage, } \\
\text { direct sowing and intercropping; long } \\
\text { term observations and photo } \\
\text { documentation of experiments }\end{array}$ & $\begin{array}{c}\text { Developing regionally adapted no-plough } \\
\text { system by combining own experience from } \\
\text { experimentation and external knowledge; } \\
\text { intensive knowledge transmission by advising } \\
\text { interested farmers }\end{array}$ \\
\hline F.2 & $\begin{array}{l}\text { Results_of } \\
\text { scientific research }\end{array}$ & $\begin{array}{l}\text { Using results of scientific research in } \\
\text { technical journals as incentive to } \\
\text { experiment about organic mildew } \\
\text { control in vine; comparing results of } \\
\text { scientific research with results of } \\
\text { own experiments }\end{array}$ & $\begin{array}{l}\text { Assessing practical implementation of scientific } \\
\text { knowledge by contrasting it with own results } \\
\text { obtained under practical conditions; acquiring } \\
\text { comprehensible knowledge about efficiency of } \\
\text { different remedies }\end{array}$ \\
\hline F.2 & $\begin{array}{l}\text { Research } \\
\text { institutions, own } \\
\text { experiences, } \\
\text { experiences of } \\
\text { other wine growers }\end{array}$ & $\begin{array}{l}\text { Experiments about mildew tolerant } \\
\text { vine varieties together with national } \\
\text { research institution (on-farm } \\
\text { research) }\end{array}$ & $\begin{array}{c}\text { Intensive knowledge exchange with researchers } \\
\text { and advisors, and national and international } \\
\text { wine growers }\end{array}$ \\
\hline F.3 & $\begin{array}{l}\text { Own experiences, } \\
\text { knowledge from } \\
\text { literature and } \\
\text { courses }\end{array}$ & $\begin{array}{l}\text { Experiments within vegetable } \\
\text { production based on farmers' own } \\
\text { experiences and on expert knowledge } \\
\text { from formal courses and literature }\end{array}$ & $\begin{array}{l}\text { Establishing regionally adapted vegetable } \\
\text { production system; intensive communication of } \\
\text { experiences with other (organic) farmers, } \\
\text { friends, volunteer workers, university students } \\
\text { and interested consumers }\end{array}$ \\
\hline F.3 & $\begin{array}{l}\text { Own experiences, } \\
\text { regional farmer } \\
\text { colleagues, organic } \\
\text { advisors }\end{array}$ & $\begin{array}{c}\text { Experiments within wine growing } \\
\text { based on combination of knowledge } \\
\text { from own experimentation over the } \\
\text { years, from experiences of farmer } \\
\text { colleagues, and from organic } \\
\text { advisors }\end{array}$ & $\begin{array}{l}\text { Adapting vineyards towards higher disease } \\
\text { tolerance }\end{array}$ \\
\hline F.4 & Farmer colleague & $\begin{array}{l}\text { Experiences of organic farmer } \\
\text { colleague motivated experiments } \\
\text { with free-range pig keeping }\end{array}$ & $\begin{array}{l}\text { Establishing regionally adapted free-range } \\
\text { system; intensive knowledge transmission (farm } \\
\text { visits, public presentations, direct } \\
\text { communication) reaching farmers, consumers, } \\
\text { chefs, etc.; intensive knowledge exchange by } \\
\text { participating in university research project about } \\
\text { animal health in organic pig production }\end{array}$ \\
\hline F.5 & $\begin{array}{l}\text { Own experience, } \\
\text { literature, organic } \\
\text { farmer colleagues; } \\
\text { research } \\
\text { institutions }\end{array}$ & $\begin{array}{l}\text { Experiments about cultivation and } \\
\text { propagation of a multitude of } \\
\text { different crops and cultivars (e.g. } \\
\text { anise; Pimpinella anisum) }\end{array}$ & $\begin{array}{l}\text { Build up extensive agro-ecological knowledge } \\
\text { about different special and unusual crops; } \\
\text { passing on knowledge by advising other } \\
\text { farmers; conducting on-farm research together } \\
\text { with research institutions }\end{array}$ \\
\hline
\end{tabular}

\subsection{Creating Opportunity for Self-Organisation}

Maintaining the capacity to self organise involves building cross-scale partnerships, responding to change in new ways or creating innovative institutional arrangements (Darnhofer, 2010). This can happen at the farm level as well as in the link between the farm and society (Darnhofer, 2010). Self-organisation develops when farmers experiment to make their farm less dependent on external influences and/or when farmers use dynamics and diversity to find creative solutions (Folke et al., 2003; Milestad \& Darnhofer, 2003).

Farming is embedded in a particular agro-ecological and socio-cultural context that exists beyond the farm gate 
and that is usually beyond the farmer's control (Quiroz, 1999). Thus, there are a variety of external influences to which farmers have to adjust. External influences are cross-scale dynamics and external drivers that impact the farm such as changing policies and subsidies, market fluctuations, powerful market actors or erratic weather events (Hanson, Hendrickson \& Archer, 2008). Experiments may aim at reducing dependence on external influences from higher scales (Bentley, 2006). Farmers F.1 and F.4 experimented in order to gain independence from external inputs (Table 5). Farmer F.1 saved fuel and material when using direct sowing, and farmer F.4 aimed for increased self-sufficiency in fodder for the pigs. Other farmers tried to become less susceptible to fluctuating markets when experimenting with direct marketing (F.3) and niche crops (F.5).

Table 5. Creating opportunity for self-organization through farmers' experiments (examples)

\begin{tabular}{|c|c|c|c|}
\hline Farmer & $\begin{array}{c}\text { External } \\
\text { dependencies / } \\
\text { dynamics }\end{array}$ & Description of experiment/activity & $\begin{array}{l}\text { Outcomes of experiment } \\
\text { (relevance for resilience) }\end{array}$ \\
\hline F.1 & $\begin{array}{l}\text { Energy inputs, fuel } \\
\text { and material }\end{array}$ & $\begin{array}{l}\text { Establishing direct sowing in cropping } \\
\text { system by continuous, successive } \\
\text { experimentation }\end{array}$ & $\begin{array}{l}\text { Consequential reduction of several } \\
\text { steps of tillage, saving time, energy, } \\
\text { fuel and material; reduction of } \\
\text { dependence on external inputs }\end{array}$ \\
\hline F.1 & $\begin{array}{c}\text { Emerging } \\
\text { opportunities, } \\
\text { spontaneous changes }\end{array}$ & $\begin{array}{l}\text { Dedicating proportion of farmland to } \\
\text { spontaneous small-scale experiments; } \\
\text { documentation of observations and } \\
\text { conclusions about incidences and } \\
\text { "mistakes" in farming system }\end{array}$ & $\begin{array}{l}\text { Keeping farming system flexible and } \\
\text { open for opportunities to conduct } \\
\text { spontaneous experiments and to react } \\
\text { to changes }\end{array}$ \\
\hline F.2 & $\begin{array}{l}\text { Occurrence of } \\
\text { diseases and pests }\end{array}$ & $\begin{array}{c}\text { Experimenting with different remedies, } \\
\text { especially against fungal infections in } \\
\text { vines }\end{array}$ & $\begin{array}{l}\text { Comprehensive and time-tested } \\
\text { knowledge about effectiveness of } \\
\text { different remedies allowed to } \\
\text { establish robust wine production } \\
\text { system }\end{array}$ \\
\hline F.3 & Market fluctuations & $\begin{array}{l}\text { Experiments with different types of } \\
\text { direct marketing (farmers' markets, } \\
\text { direct selling on farm, self-harvest } \\
\text { vegetable allotments) }\end{array}$ & $\begin{array}{l}\text { Establishment of diversified direct } \\
\text { marketing system and constitution of } \\
\text { loyal consumer stock, leading to more } \\
\text { independence from market } \\
\text { fluctuation }\end{array}$ \\
\hline F.4 & $\begin{array}{l}\text { Rising costs for } \\
\text { fodder inputs }\end{array}$ & Experiments with sunchoke (Helianthus & $\begin{array}{c}\text { More independence from fodder } \\
\text { purchase in times of rising costs for } \\
\text { cereal }\end{array}$ \\
\hline F.4 & $\begin{array}{l}\text { Risk of } \\
\text { contamination with } \\
\text { genetically modified } \\
\text { organisms in fodder }\end{array}$ & $\begin{array}{l}\text { tuberosus) as fodder base for extensive } \\
\text { free-range pig fattening system }\end{array}$ & $\begin{array}{l}\text { Using sunchoke as alternative for } \\
\text { maize or soybean as fodder base for } \\
\text { pigs, allowing clear dissociation from } \\
\text { genetically modified fodder inputs }\end{array}$ \\
\hline F.5 & $\begin{array}{l}\text { Declining market } \\
\text { prices, rising market } \\
\text { competition }\end{array}$ & $\begin{array}{l}\text { Continuous experiments with } \\
\text { alternative niche crops }\end{array}$ & $\begin{array}{l}\text { Developing extensive know-how } \\
\text { about growing niche crops; having } \\
\text { the possibility to shift to more } \\
\text { profitable crops in case of declining } \\
\text { market prices, based on practical } \\
\text { experiences }\end{array}$ \\
\hline
\end{tabular}

\section{Conclusion}

Conventional research has long overlooked the active and creative role of farmers in innovation processes (Chambers et al., 1989; Röling \& Wagemakers, 1998; Chikozho, 2005; Leitgeb et al., 2011). However, scientists and extension agents increasingly recognize the key role of innovative farmers and acknowledge their experiments and innovations for agricultural development. Numerous examples for participatory research and development indicate that the innovative capacity of farmers, research activities of scientists and other stakeholders engaged in rural development merge (e.g. Reij and Waters-Bayer, 2001; Vaarst et al., 2007; Leitgeb et al., 2011). The inclusion of farmers' knowledge increases the likelihood that knowledge that is developed in such processes is relevant to farmers and their farms. It is vital that agricultural innovations as such also contribute to the sustainable development of farming systems. In the context of management of natural resources and ecosystem services, modern agriculture cannot boast a good record (Millenium Ecosystem Assessment, 2005). Further, adaptation to climate change will put additional strain on the sustainability of farming systems. Thus, we suggest that the 
knowledge development that farmers carry out through experimentation should not only be acknowledged in research and advisory systems, but also for its capacity to enhance sustainability. Resilience thinking offers a framework for understanding if this is the case by providing understanding for the dynamics of complex systems and by presenting insights on what makes a system less vulnerable.

The five cases used in our analysis were selected to show the potential of farmers' experiments to build social-ecological resilience. The farmers presented in this study all work full time on their farms, and have large social networks. Further, their farms are situated in areas where soil and climate allow for a multitude of cropping systems, which increases the opportunities to try new things. At the same time, some of the farms are subject to a dry climate, inducing change and the need to develop a robust farming system. In short, the cases correspond with the type of farmer that has been found to experiment in other studies (Saad, 2002). For all four resilience-building principles (Folke et al., 2003) we found examples from each farm of experiments initiated and carried out by the farmers themselves. Thus, these five farmers and farmer couples experiment in ways that could be argued to enhance social-ecological resilience at the farm and in the region.

The analytical separation of the principles building social-ecological resilience and the different experiments farmers carry out partly mask the fact that the four principles overlap and that farmers' experiments are complex processes. For the purposes of this study the analytical separation was useful, but it is important to remember that experiments can involve long series of smaller interrelated experiments and that farmers' experiments should not be seen as single, linear processes (Kummer, 2011). In addition, the proposed principles that build social-ecological resilience clearly overlap and create synergies (Darnhofer, 2010). For example, introduction of diversity (principle 2) can be used as a risk spreading strategy (principle 1) and different knowledge systems (principle 3) can be used to enhance social diversity (principle 2).

In this study, we allocated the different experiments to the principle with the strongest connection, but one experiment can very well strengthen more than one or all four principles. For example, farmer F.1 carried out experiments to reduce risks by using diversity of crops and at the same time succeeded in reducing external dependences and build self-organisation (principle 4). The reduced tillage improved the structure and fertility of the soil by allowing more biological activity to develop. This, in combination with use of intercropping, reduced the risk of production failures when the weather was dry or when one crop failed due to other reasons. In the same experiment, farmer F.1 used diverse sources of knowledge (principle 3) and also acted as an expert and advisor on low-tillage organic agriculture to spread the knowledge developed in his experiments.

If an experiment is done along the lines of one or more of the principles that build social-ecological resilience, it can be argued to enhance farm resilience. In the examples presented in this paper this was the case. However, this does not mean that all experiments necessarily build resilience. If an experiment puts the farm at risk (e.g. experimenting on too large scale), if it makes the farm more dependent on external resources (e.g. experiments that increase off-farm purchases), or if it reduces diversity (e.g. experiments that aim to maximise output of one product at the expense of others), then farm resilience is likely to erode in the long term. When supporting or advising farmers, it is therefore important to raise awareness for possible risks of experimentation. A resilience framework can help to distinguish between risky experimentation and experiments that support sustainable development of the farm. In this context it is important to stress that resilience, unlike sustainability, can be desirable or undesirable, and also undesirable systems can be highly resilient (Carpenter et al., 2001). When evaluating resilience of farmers' experiments, it is therefore also crucial to assess if the particular experiment contributes to a desirable farming system.

The possibility for farmers to carry out resilience-building experiments is influenced by regulations, subsidy systems and support payments. For example, all farmers in this study had to adhere to the European Union regulation for organic farming. Thus, even on a small and risk-free scale, they would not be able to experiment on things not allowed in the organic regulation. Also contracts for direct payments in the framework of the EU agri-environmental programs may limit farmers' possibilities to experiment. Additionally, in the context of food processing, farmers confront regulations (e.g. hygiene standards) that limit the options for experimentation. On the other hand, regulations and different agricultural support programs can also been seen as limitations spurring experimentation. This was the case for farmer F. 4 who started a lot of experimentation after converting to organic farming and changing his whole production system. For the organic pioneer farmers (F.1, F.2, F.3, F.5) experimentation was an integral part of being an organic farmer before extension systems had been developed.

In the quest for sustainable development of farming systems, it is crucial to take account of the resilience-building experiments that take place at the farm level and to give farmers room for creativity within regulatory frameworks. Therefore, it is important to develop policy tools and/or create conducive conditions that support farmers in their 
experimenting role or at least do not inhibit farmers' experiments. For example, subsidy systems could be developed that give farmers a range of possibilities to fulfil a policy measure rather than only one option. Along with the promising strategies to involve farmers in advisory and research systems through participatory approaches, supporting farmers' experiments can enhance the sustainable development of farming systems.

\section{Acknowledgements}

The Austrian Science Foundation (FWF) and the Swedish Research Council for Environment, Agricultural Sciences and Spatial Planning (FORMAS) funded this research. We are also grateful to Ika Darnhofer, Christine van der Stege, Heidemarie Pirker, Ruth Haselmair and Racheli Ninio for the fruitful discussions on this topic, and for comments on earlier drafts of this paper.

\section{References}

Alcorn, J. B., Bamba, J., Masiun, S., Natalia, I., \& Royo, A. G. (2003). Keeping ecological resilience afloat in cross-scale turbulence: an indigenous social movement navigates change in Indonesia. In F. C. J. Berkes and C. Folke (Eds.), Navigating Social-ecological Systems: Building Resilience for Complexity and Change. Cambridge, Cambridge University Press: pp. 299-327.

Armitage, D., Marschkeb, M., \& Plummerc, R. (2008). Adaptive co-management and the paradox of learning. Global Environmental Change, 18(1), 86-98. http://dx.doi.org/10.1016/j.gloenvcha.2007.07.002

Bennet, E. M., Cumming, G. S., \& Peterson, G. D. (2005). A systems model approach to determining resilience surrogates for case studies. Ecosystems, 8, 945-957. http://dx.doi.org/10.1007/s10021-005-0141-3

Bentley, J. W. (2006). Folk experiments. Agriculture and Human Values, 23, 241-462. http://dx.doi.org/10.1007/s10460-006-9017-1

Berkes, F., \& Turner, N. (2006). Knowledge, learning and the evolution of conservation practice for

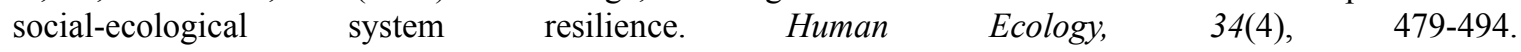
http://dx.doi.org/10.1007/s10745-006-9008-2

Berkes, F. (2007). Understanding uncertainty and reducing vulnerability: lessons from resilience thinking. Natural Hazards, 41, 283-295. http://dx.doi.org/10.1007/s11069-006-9036-7

Berkes, F., Colding, J., \& Folke, C. (2000). Rediscoverty of traditional ecological knowledge as adaptive $\begin{array}{llll}\text { management. } & \text { Ecological } & \text { Applications, } & 10(5),\end{array}$ http://dx.doi.org/10.1890/1051-0761(2000)010[1251:ROTEKA]2.0.CO;2

Bernard, H. R. (2006). Research Methods in Anthropology. Qualitative and Quantitative Approaches (2nd ed.). Oxford, Altamira Press.

Björklund, J., Westberg, L., Geber, U., Milestad, R., \& Ahnström, J. (2009). Local selling as a driving force for increased on-farm biodiversity. Journal of Sustainable Agriculture, 33, 885-902. http://dx.doi.org/10.1080/10440040903303694

Buchmann, C. (2009). Cuban homegardens and their role in social-ecological resilience. Human Ecology, 37(6), 705-721. http://dx.doi.org/10.1007/s10745-009-9283-9

Bundesministerium für Land- und Forstwirtschaft, Umwelt und Wasserwirtschaft [BMLFUW] (2011). Grüner Bericht 2011. Bericht über die Situation der österreichischen Land- und Forstwirtschaft. [Report on the status of agriculture in Austria in 2011, Federal Ministry of Agriculture, Forestry, Environment and Water Management], Vienna, Austria.

Carpenter, S. R. B., Walker, J., Anderies, M., \& Abel, N. (2001). From metaphor to measurement: resilience of what to what? Ecosystems, 4, 765-781. http://dx.doi.org/10.1007/s10021-001-0045-9

Chambers, R., Pacey, A. \& Thrupp, L. A., Eds. (1989). Farmer First: Farmer Innovation and Agricultural Research. London, Intermediate Technology Publications.

Chikozho, C. (2005). Policy and institutional dimensions of small-holder farmer innovations in the Thukela River Basin of South Africa and the Pangani River Basin of Tanzania: a comparative perspective. Physics and Chemistry of the Earth, 30, 913-924. http://dx.doi.org/10.1016/j.pce.2005.08.038

Critchley, W. R. S., \& Mutunga, K. (2003). Local innovation in a global context: documenting farmer initiatives in land husbandry through WOCAT. Land Degradation and Development, 14, 143-162. http://dx.doi.org/10.1002/ldr.537

Critchley, W. R. S. (2000). Inquiry, initiative and inventiveness: farmer innovators in East Africa. Physics and 
Chemistry of the Earth, 25(3), 285-288. http://dx.doi.org/10.1016/S1464-1909(00)00016-2

Cumming, G. S., Barnes, G., Perez, S., Schmink, M., Sieving, K. E., Southworth, J., Binford, M., Holt, R. D., Stickler, C., \& Van, V. H. T. (2005). An exploratory framework for the empirical measurement of resilience. Ecosystems, 8, 975-987. http://dx.doi.org/10.1007/s10021-005-0129-z

Darnhofer, I. (2010). Strategies of Family Farms to Strengthen their Resilience. Environmental Policy and Governance, 20(4), 212-222. http://dx.doi.org/10.1002/eet.547

Ellis, F. (2000). Rural Livelihoods and Diversity in Developing Countries. Oxford and New York, Oxford University Press.

Folke, C., Colding, J., \& Berkes, F. (2003). Synthesis: building resilience and adaptive capacity in social-ecological systems. In C. Folke, J. Colding and F. Berkes, Navigating Social-ecological Systems: Building Resilience for Complexity and Change. Cambridge, Cambridge University Press: pp. 352-387.

Gupta, A. (2000). Grassroots innovations for survival. ILEIA newsletter. 16, 5-6.

Hanson, J. D., Hendrickson, J., \& Archer, D. (2008). Challenges for maintaining sustainable agricultural systems in the United States. Renewable Agriculture and Food Systems, 23(4), 325-334. http://dx.doi.org/10.1017/S1742170507001974

Haverkort, B. (1991). Farmer's experiments and participatory technology development. In B. Haverkort, J. V. D. Kamp and A. Waters-Bayer, Joining Farmer's Experiments. London, Intermediate Technology Publications.

Hendrickson, J., Sassenrath, G. F., Archer, D., Hanson, J., \& Halloran, J. (2008). Interactions in integrated US agricultural systems: the past, present and future. Renewable Agriculture and Food Systems, 23(4), 314-324. http://dx.doi.org/10.1017/S1742170507001998

Hoffmann, V., Probst, K., \& Christinck, A. (2007). Farmers and researchers: how can collaborative advantages be created in participatory research and technology development? Agriculture and Human Values, 24(3), 355-368. http://dx.doi.org/10.1007/s10460-007-9072-2

IAASTD (2009). International Assessment of Agricultural Knowledge, Science and Technology for Development. Global report. Washington D.C., Island Press.

Johnson, A. W. (1972). Individuality and experimentation in traditional agriculture. Human Ecology 1: 149-159. http://dx.doi.org/10.1007/BF01531352

Kroma, M. M. (2006). Organic farmer networks: facilitating learning and innovation for sustainable agriculture. Journal of Sustainable Agriculure, 28(4), 5-28. http://dx.doi.org/ 10.1300/J064v28n04_03

Kummer, S. (2011). Organic farmers' experiments in Austria. Learning processes and resilience building in farmers' own experimentation activities. Dissertation. Vienna, University of Natural Resources and Life Sciences, Dept. of Sustainable Agricultural Systems.

Leitgeb, F., Funes-Monzote, F., Kummer, S., \& Vogl, C. R. (2011). Contribution of farmers' experiments and innovations to Cuba's agricultural innovation system. Renewable Agriculture and Food Systems. http://dx.doi.org/10.1017/S1742170511000251

Miles, M. B., \& Huberman, A. M. (1994). Qualitative Data Analysis. An Expanded Sourcebook (2nd ed.). London, Sage Publications.

Milestad, R., \& Darnhofer, I. (2003). Building farm resilience: the prospects and challenges of organic farming. Journal of Sustainable Agriculture, 22(3), 81-97. http://dx.doi.org/10.1300/J064v22n03_09

Milestad, R., Westberg, L., Geber, U. \& Björklund, J. (2010). Enhancing Adaptive Capacity in Food Systems: Learning at Farmers' Markets in Sweden. Ecology and Society 15(3). http://www.ecologyandsociety.org/vol15/iss3/art29/

Millar, D. (1994). Experimenting farmers in Northern Ghana. In I. Scoones and J. Thompson, Beyond Farmer First: Rural People's Knowledge, Agricultural Research and Extension Practice. London, Intermediate Technology Publications: pp. 160-165.

Millenium Ecosystem Assessment (2005). Ecosystems and human well-being: synthesis. Washington DC., Island Press.

Nyström, M., \& Folke, C. (2001). Spatial resilience of coral reefs. Ecosystems, 4, 406-417. http://dx.doi.org/10.1007/s10021-001-0019-y 
Padel, S. (2001). Conversion to organic farming: A typical example of the diffusion of an innovation? Sociologia Ruralis 41: 40-61. http://dx.doi.org/10.1111/1467-9523.00169

Pretty, J. (1998). The Living Land. Agriculture, Food and Community Regeneration in Rural Europe. London, Earthscan Publications Ltd.

Quiroz, C. (1999). Farmer experimentation in a Venezuelan Andean group. In G. Prain, S. Fujisaka and M. D. Warren, Biological and Cultural Diversity. The Role of Indigenous Agricultural Experimentation in Development. London, Intermediate Technology Publications: pp. 113-124.

Reij, C., \& Waters-Bayer, A. (2001). An initial analysis of farmer innovators and their innovations. In C. Reij and A. Waters-Bayer, Farmer innovation in Africa. A source of inspiration for agricultural development. London, Earthscan: pp. 77-91.

Rhoades, R., \& Bebbington, A. (1991). Farmers as experimenters. In B. Haverkort, J. van der Kamp and A. Waters-Bayer, Joining Farmers' Experiments. Experiences in Participatory Technology Development. London, Intermediate Technology Publications, 251-253.

Richards, M., \& Suazo, L. (2006). Learning from success: revisiting experiences of LEIT adoption by hillside farmers in central Honduras. In R. Tripp, Self-sufficient agriculture: labour and knowledge in small-scale farming. Sterling, Earthscan.

Röling, N., \& Brouwers, J. (1999). Living local knowledge for sustainable development. In G. Prain, S. Fujisaka and M. D. Warren, Biological and Cultural Diversity. The Role of Indigenous Agricultural Experimentation in Development. London, Intermediate Technology Publications: pp. 147-157.

Röling, N. \& Wagemakers, W. A. E., Eds. (1998). Facilitating Sustainable Agriculture. Participatory Learning and Adaptive Management in Times of Environmental Uncertainty. Cambridge, Cambridge University Press.

Saad, N. (2002). Farmer processes of experimentation and innovation. A review of the literature. CGIAR systemwide program on participatory research and gender analysis. Working Document Nr. 21.

Scheuermeier, U. (1997). Let's try it out and see how it works. In L. Van Veldhuizen, A. Waters-Bayer, R. Ramírez, D. A. Johnson and J. Thompson, Farmers' Research in Practice. Lessons from the Field. London, Intemediate Technology Publications.

Scoones, I., \& Thompson, J., Eds. (1994). Beyond Farmer First. Rural People's Knowledge, Agricultural Research and Extension Practice. London, Intermediate Technology Publications.

Stolzenbach, A. (1999). The indigenous concept of experimentation among Malian farmers. In G. Prain, S. Fujisaka and M. D. Warren, Biological and Cultural Diversity. The Role of Indigenous Agricultural Experimentation in Development. London, Intermediate Technology Publications: 163-171.

Sturdy, J. D., Jewitt, G. P. W., \& Lorentz, S. A. (2008). Building an understanding of water use innovation adoption processes through farmer-driven experimentation. Physics and Chemistry of the Earth, 33, 859-873. http://dx.doi.org/10.1016/j.pce.2008.06.022

Sumberg, J., \& Okali, C. (1997). Farmers' Experiments. Creating Local Knowledge. London, Lynne Rienner Publishers.

Vaarst, M., Nissen, T. B., Østergaard, S., Klaas, I. C., Bennedsgaard, T. W., \& Christensen, J. (2007). Danish stable schools for experiential common learning in groups of organic dairy farmers. Journal of dairy science, 90(5), 2543-2554. http://dx.doi.org/10.3168/jds.2006-607

Van Veldhuizen, L., Waters-Bayer, A., Ramirez, R., Johnson, D. A., \& Thompson, J., Eds. (1997). Farmers' Research in Practice. Lessons from the Field. London, Intermediate Technology Publications.

Vogl, C. R., Axmann, P., \& Vogl-Lukasser, B. (2004). Urban organic farming in Austria with the concept of Selbsternte ('self-harvest'): An agronomic and socio-economic analysis. Renewable Agriculture and Food Systems, 19(2), 67-69. http://dx.doi.org/10.1079/RAFS200062

Walker, B., Gunderson, L., Kinzig, A., Folke, C., Carpenter, S., \& Schultz, L. (2006). A handful of heuristics and some propositions for understanding resilience and social-ecological systems. Ecology and Society, 11(1), 13. http://www.ecologyandsociety.org/vol11/iss1/art13/

Walker, B., Holling, C. S., Carpenter, S. R., \& Kinzig, A. (2004). Resilience, adaptability and transformability in social-ecological systems. Ecology and Society, 9(2), 5. http://www.ecologyandsociety.org/vol9/iss2/art5/ 
Wilbois, K. P., Schwab, A., Fischer, H., Bachinger, J., Palme, S., Peters, H., \& Dongus, S. (2004). Leitfaden für Praxisversuche. Eine Anleitung zur Planung, Durchführung und Auswertung von Praxisversuchen. Frankfurt a.M., FiBL Deutschland e.V.

Wu, B., \& Pretty, J. (2004). Social connectedness in marginal rural China: The case of farmer innovation circles in Zhidan, north Shaanxi. Agriculture and Human Values, 21, 81-92. http://dx.doi.org/10.1023/B:AHUM.0000014025.47576.72 